\title{
Bupropion-induced leukopenia: A case report
}

\author{
Bupropiona bağlı gelişen lökopeni: Bir olgu sunumu
}

\author{
Gamze Gürcan ${ }^{1}$, Ahmet Gürcan² \\ $1_{M}$ M. D., Department of Psychiatry, Akdağmadeni State Hospital, Yozgat, Turkey https://orcid.org/0000-0001-9896-8869 \\ 2M.D. Department of Psychiatry, Baskent University Medical Faculty, Ankara, Turkey https://orcid.org/0000-0002-3545-8981
}

\section{SUMMARY}

Bupropion hydrochloride, a norepinephrine/dopamine reuptake inhibitor, is administered for the treatment of depression and smoking cessation. Common side effects of bupropion are dry mouth, nausea and insomnia, also it may lower the seizure threshold. The normal range of total white blood cell (WBC) count is $4000-11000 / \mu \mathrm{l}$ for adults. The values below $4000 / \mu \mathrm{l}$, are defined as leukopenia.

A 33-year-old woman admitted to the psychiatry outpatient clinic with the complaints of mild depression, also wanted to quit smoking. Bupropion hydrochloride (extended release-XL) $150 \mathrm{mg} /$ day was initiated to the patient. The leukocyte count of her treatment was $3890 / \mu \mathrm{l}$ at the third month and 3730/ $\mu \mathrm{l}$ at the fourth month. The leukocyte count was at normal value before initiation of bupropion hydrochloride $(7220 / \mu \mathrm{l})$ and after stopping the treatment $(7290 / \mu \mathrm{l})$. She did not have any chronic disease, medication and drug or alcohol abuse. According to this case, it is probable that there was a relationship between bupropion hydrochloride and leukopenia as an adverse event.

Many idiosyncratic drug reactions involve blood dyscrasias. Some of the psychotropic drugs have been associated with leukopenia and sometimes agranulocytosis. Although some rare studies and case reports related to leukopenia have been reported with some of the antidepressants but to our knowledge bupropion induced leukopenia is not a common side effect. Therefore, reporting this adverse event due to bupropion is important to make a contribution to literature.

Key Words: Bupropion, leukopenia, adverse effect

\section{ÖZET}

Bupropion hidroklorür depresyon ve sigara bırakma tedavisinde kullanılan bir norepinefrin / dopamin geri alım inhibitörüdür. Sıklıkla görülen yan etkileri ağız kuruluğu, bulantı ve uykusuzluktur, ayrıca nöbet eşiğini düşürebilir. Beyaz kan hücresi (lökosit) sayısının normal aralığı yetişkinler için $4000-11000$ / $\mu$ l'dir. 4000 / $\mu$ l'nin altındaki değerler lökopeni olarak tanımlanır.

Hafif depresyon belirtileri ile psikiyatri polikliniğine başvuran 33 yaşındaki kadın hasta mevcut yakınmalarının yanında sigarayı bırakmak istediğini belirtmiş, hastaya bupropion hidroklorür (uzatılmış salınım-XL) 150 mg/gün tedavisi başlanmıştır. Tedavisinin üçüncü ayında lökosit sayısı 3890/ $\mu$ l, dördüncü ayda $3730 / \mu$ l olarak saptanmış olup, tedavi öncesi $(7220 / \mu$ l) ve tedavi kesildikten sonra $(7290 / \mu \mathrm{l})$ bu değerlerin normal aralıkta olduğu görülmüştür. Hastanın herhangi bir kronik hastalığı, ilaç, alkol veya madde bağımlılığı olmadığı öğrenilmiştir. Bu olguya göre bupropion hidroklorür ile lökopeni arasında bir ilişki olması muhtemeldir.

Kan diskrazileri idiyosenkratik ilaç reaksiyonlarından biridir. Psikotrop ilaçların bazıları lökopeni ve agranülositoz ile ilişkilendirilmiştir. Antidepresan tedavisiyle lökopeni gözlenen nadir çalışmalar ve olgular bildirilmiş olsa da, bupropiyona bağlı lökopeni sık görülen bir yan etki değildir. Bu nedenle bupropiyona bağlı bu etkinin bildirilmesi, literatüre katkı sağlaması açısından önemlidir.

Anahtar Sözcükler: Bupropion, lökopeni, yan etki

(Turkish J Clinical Psychiatry 2021;24:416-419)

DOI: $10.5505 / \mathrm{kpd} .2021 .02419$ 


\section{INTRODUCTION}

Bupropion hydrochloride, a norepinephrine/ dopamine reuptake inhibitor, is administered for the treatment of depression and smoking cessation $(1,2)$. Bupropion hydrochloride differs structurally from first-generation tricyclic antidepressants (TCAs) and second-generation selective serotonin reuptake inhibitor (SSRI) antidepressants with having no direct action on the serotonin system, so categorized as an atypical antidepressant $(2,3)$. Common side effects of bupropion are dry mouth, nausea and insomnia (4), also it may lower the seizure threshold (2). On the other hand, sexual dysfunction, weight gain and sedation do not occur frequently like other antidepressants (2). Bupropion is available in three bioequivalent oral formulations: immediate release (IR), sustained release (SR), and extended release (XL) (1).

The normal range of total white blood cell (WBC) count is $4000-11000 / \mu \mathrm{l}$ for adults. The values below $4000 / \mu \mathrm{l}$, are defined as leukopenia. Many psychotropic drugs have been associated with leukopenia and sometimes even agranulocytosis. Clozapine and carbamazapine are widely known for these side effects $(5,6)$. Blood count monitoring has reduced the associated morbidity and mortality. Blood dyscrasias occur usually within the first few months of pharmacotherapy with the drugs like clozapine associated with hypersensitivity. On the other hand, these adverse events may develop at any time with the drugs that have toxic properties on the bone marrow like carbamazepine $(5,6,7,8)$. Although some rare studies and case reports related to leukopenia have been reported with some of the antidepressants (mirtazapine, SSRIs, TCAs, venlafaxine, trazodone) (5), to our knowledge there is one case report (9) indicating bupropion induced leukopenia.

\section{CASE REPORT}

A 33-year-old woman admitted to the psychiatry outpatient clinic with the complaints of mild depression. She said that her mood was depressed and was feeling fatigued, not interested in doing things she normally enjoyed and slept more than she did before for the last two months. Also, she had history of smoking for five years and wanted to quit smoking. She had shown symptoms like psychomotor retardation, anhedonia and hypersomnia, but the symptoms were not severe and psychosocial functioning of the patient was substantially preserved. She had no suicidal ideation, no feelings of worthlessness or inappropriate guilt, and no change in appetite. According to the medical history obtained, she had an episode of depression which was similar to the current episode two years ago, and escitalopram was prescribed. But she did not continue the escitalopram treatment due to the sedation which was a side effect. She did not have any chronic disease, medication, drug or alcohol abuse.

Bupropion hydrochloride (extended release-XL) $150 \mathrm{mg} /$ day was initiated with the diagnosis of mild depression. The reasons for choosing this treatment were the request to quit smoking, the presence of psychomotor retardation and fatigue, and the discontinuation of escitalopram because of sedation in the past medical history. It was learned that, some blood tests were performed at regular intervals to the patient because she was a healthcare worker. After three months of initiation of the treatment, leukocyte count was $3890 / \mu l$ in the patient's routine blood test examination. The other blood tests (other values of complete blood count CBC-), serum biochemistry panel, vitamin B12, folate, thyroid function tests) were normal. Her physical examination did not show any pathological finding, and she did not have any physical complaint. When the patient's medical records were investigated retrospectively, it was understood that the leukocyte count was at normal value $(7220 / \mu \mathrm{l})$ six months before the initiation of bupropion hydrochloride treatment. The patient was asked to repeat the test one week later to confirm the laboratory tests, and to evaluate any transient change in leukocyte count. But the patient did not comply this recommendation and had the $\mathrm{CBC}$ one month later, also she had continued bupropion hydrochloride treatment during this period. One month later (the fourth month of initiation of the treatment) she applied to psychiatry outpatient clinic, and leukocyte count was 3730/ $\mu$ l. Bupropion hydrochloride was stopped and a new treatment was not started due to the relief of the patient's mild depressive symptoms. During this period, she did 
Iable 1. Laboratery values of the patient

\begin{tabular}{|c|c|c|c|}
\hline & Leukocyte Count & & \\
\hline & & Neutrophal $(\%)$ & Lymphocyte $(\%)$ \\
\hline 6 months before treatment & $7220 \cdot \mu 1$ & $72.1 \%$ & $11.8 \%$ \\
\hline 3 months after treatment & $3890 \mathrm{Ml}$ & $48 \%$ & $37.5 \%$ \\
\hline 4 mooths after treatment & $3730 \mathrm{\mu l}$ & $50.9 \%$ & $35.7 \%$ \\
\hline I month after stopping treatment & $5940 . \mu 1$ & $66.1 \%$ & $18.5 \%$ \\
\hline 7 months after stopping treatment & $7290 \mathrm{\mu l}$ & $703 \%$ & $20.1 \%$ \\
\hline
\end{tabular}

not quit smoking. One month after cessation of the treatment, leukocyte count was increased to $5940 / \mu 1$. She had no depressive symptoms and her mental status examination was normal, so she was followed-up without pharmacotherapy. When the last medical records of the patient were investigated, it was seen that her leukocyte count was $7290 / \mu \mathrm{l}$ seven months after stopping bupropion hydrochloride treatment. Leukocyte counts, percentages of neutrophils and lymphocytes with time of the blood tests are presented in Table 1.

\section{DISCUSSION}

The patient who had no previous medical issue other than a depressive episode admitted with mild depressive complaints. She did not have any chronic disease, medication, drug or alcohol abuse. Bupropion was suggested for both her complaints and smoking cessation. The leukocyte count at the

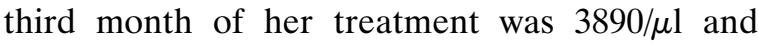
$3730 / \mu \mathrm{l}$ at the fourth month. The leukocyte count was at normal value before initiation of bupropion hydrochloride $(7220 / \mu \mathrm{l})$ and after stopping the treatment $(7290 / \mu \mathrm{l})$. According to this case, it is probable that there was a relationship between bupropion hydrochloride and leukopenia as an adverse event.

Many idiosyncratic drug reactions involve blood dyscrasias. Drugs can cause immune-related hypersensitivity and bone marrow toxicity, because of the role of leukocytes in the induction of an immune response by interaction of reactive metabolites of drugs with leukocytes $(7,8)$. Some of the psychotropic drugs have been associated with leukopenia and sometimes agranulocytosis (10), but to our knowledge bupropion induced leukopenia is not a common side effect (5). In a case report, leukopenia was reported with a combination of psychotropic medications including bupropion but it was associated with lamotrigine due to temporal features of the symptoms (11). In a brief report, leukopenia was reported with a combination of echinacea and bupropion (12) and it was associated with Echinacea, but it was discussed that bupropion might exacerbate the leukopenic effect of echinacea. Previous case presentations reported a variety of hematologic side effects such as eosinophilia and leukocytosis with bupropion and there was only one case presentation (9) that reported leukopenia without neutropenia with bupropion. Therefore, reporting this adverse event due to bupropion is important to contribute to literature. Leukopenia or neutropenia were reported with different dopaminergic drugs $(13,14)$, therefore shared effects of these drugs might be investigated with future studies to reveal any possible mechanism.

Absence of peripheral blood smear and the lack of laboratory investigations which could identify the potential causes also lead to the decrease in leukocyte count like viral infections or toxic events are some limitations of this case report.

\section{Funding Sources}

This research received no specific grant from any funding agency in the public, commercial, or notfor-profit sectors.

\section{Conflict of interest statement}

The authors declare no conflicts of interest in preparing this article.

Correspondence address: M. D. Ahmet Gurcan, Department of Psychiatry, Baskent University Medical Faculty, Ankara, Turkey agurcang@gmail.com 


\section{REFERENCES}

1. Khan SR, Berendt RT, Ellison CD, Ciavarella AB, AsafuAdjaye E, Khan MA, Faustino PJ. Bupropion Hydrochloride. Profiles Drug Subst Excip Relat Methodol 2016; 41:1-30.

2. Stahl SM, Pradko JF, Haight BR, Modell JG, Rockett CB, Learned-Coughlin S. A review of the neuropharmacology of bupropion, a dual norepinephrine and dopamine reuptake inhibitor. Prim Care Companion J Clin. Psychiatry 2004; 6:159166.

3. Stahl SM. Basic psychopharmacology of antidepressants, part 1: antidepressants have seven distinct mechanisms of action. J Clin Psychiatry 1998; 59:5-14.

4. Settle EC, Stahl SM, Batey SR, Johnston JA, Ascher JA. Safety profile of sustained-release bupropion in depression: results of three clinical trials. Clin Ther 1999; 3:454-463.

5. Sedky K, Lippmann S. Psychotropic Medications and Leukopenia. Curr Drug Targets 2006; 7:1191-4.

6. Stübner S, Grohmann R, Engel R, Bandelow B, Ludwig WD, Wagner G, Muller-Oerlinghausen B, Moller HJ, Hippius H, Ruther E. Blood Dyscrasias Induced by Psychotropic Drugs. Pharmacopsychiatry 2004; 37 (Suppl 1):S70-8.

7. Uetrecht JP. The role of leukocyte-generated reactive metabolites in the pathogenesis of idiosyncratic drug reactions. Drug Metab Rev 1992; 24:299-366.

8. Williams DP, Pirmohamed M, Naisbitt DJ, Uetrecht JP, Park BK. Induction of Metabolism-Dependent and -Independent Neutrophil Apoptosis by Clozapine. Mol Pharmacol 2000; 58:207-16.

9. Reyes PN, Cross D. Depression, medication, and 'bad blood'. Curr Psychiatr 2007; 6(5):97-100.

10. Ouesanmi O, Kunkel EJS, Monti DA, Field HL Hematologic side effects of psychotropics. Psychosomatics 1999; 40:414-421.

11. Solvason HB. Agranulocytosis Associated With Lamotrigine. Am. J. Psychiatry 2000; 157:1704.

12. Kemp DE, Franco KN. Possible leukopenia associated with long-term use of echinacea. J. Am. Board Fam. Pract. 2002; 15:417-19.

13. Butt MI, Waheed N. Recurrent neutropenia due to dopamine agonists in a patient with microprolactinoma. Endocr. Pract. 2013; 19:122-23.

14. Scarnati R. An outline of hazardous side effects of ritalin (methylphenidate). Subst Use Misuse. 1986;21:837-41. 